\title{
Au-NANOPARTICLE SYNTHESIS VIA ULTRASONIC SPRAY PYROLYSIS WITH A SEPARATE EVAPORATION ZONE
}

\author{
SINTEZA NANODELCEV ZLATA Z ULTRAZVOČNO RAZPRŠILNO \\ PIROLIZO Z LOČENO CONO IZHLAPEVANJA
}

\author{
Peter Majerič ${ }^{1}$, Bernd Friedrich ${ }^{2}$, Rebeka Rudolf ${ }^{1,3}$ \\ ${ }^{1}$ University of Maribor, Faculty of Mechanical Engineering, Smetanova ulica 17, 2000 Maribor, Slovenia \\ ${ }^{2}$ RWTH Aachen University, IME Process Metallurgy and Metal Recycling, Germany \\ ${ }^{3}$ Zlatarna Celje d.d., Kersnikova ulica 19, 3000 Celje, Slovenia \\ peter.majeric@um.si \\ Prejem rokopisa - received: 2014-10-17; sprejem za objavo - accepted for publication: 2014-11-11
}

doi:10.17222/mit.2014.264

\begin{abstract}
Some experiments were conducted in connection with the gold-nanoparticle production in an effort to produce a more accurate model for determining the gold-nanoparticle synthesis with a modified ultrasonic spray pyrolysis (USP). As previous experiments with gold nanoparticles yielded nanoparticles of various shapes (spherical, triangular, cylindrical, etc.), a focus on synthesizing only spherical nanoparticles is underway, as a mixture of different shapes is difficult to characterize and utilize. One of the factors for the particle formation is droplet evaporation. In an attempt to produce the optimum conditions for droplet evaporation with the solvent diffusion and precipitation, a separate furnace and a separate reaction-gas inlet were used. This modification separates the evaporation stage from the reaction stage, compared to the standard USP set-up. Using relatively low temperatures, from $60{ }^{\circ} \mathrm{C}$ up to $140{ }^{\circ} \mathrm{C}$, for the evaporation stage provides for more time and better conditions for the diffusion of the solvent into the center of a droplet and a higher probability of forming a spherical particle.

Keywords: ultrasonic spray pyrolysis, gold nanoparticles, aerosol droplet evaporation, TEM microscopy
\end{abstract}

Prispevek opisuje sintezo nanodelcev zlata, ki smo jo izvedli z modificirano ultrazvočno razpršilno pirolizo (USP) s ciljem postavitve čim bolj realnega teoretičnega modela. Pri prejšnjih eksperimentih sinteze nanodelcev zlata smo dobili nanodelce različnih oblik (sferične, trikotne, cilindrične, itd.), zato smo se pri tej raziskavi osredinili na izdelavo sferičnih nanodelcev. Morfološko različni nanodelci so ovira ne samo pri karakterizaciji, ampak tudi kasneje pri sami uporabi. Pri sintezi nanodelcev ima velik vpliv na končno morfologijo izhlapevanje kapljic aerosola. Za zagotovitev razmer za izhlapevanje kapljic, ki omogočajo nastanek sferičnih nanodelcev, smo v procesu USP uporabili ločeno ogrevalno območje in ločen vnos reakcijskega plina. Ta modifikacija namreč ločuje stopnjo izhlapevanja od stopenj reakcij za nastanek nanodelcev. Nižja temperatura v fazi izhlapevanja (med $60^{\circ} \mathrm{C}$ in $140^{\circ} \mathrm{C}$ ) omogoča boljšse razmere za difuzijo topljenca do središča kapljice in večjo verjetnost nastanka sferičnih nanodelcev.

Ključne besede: ultrazvočna razpršilna piroliza, zlati nanodelci, izhlapevanje kapljic aerosola, TEM-mikroskopija

\section{INTRODUCTION}

Spray pyrolysis is a well-known method for obtaining nanoparticles of various shapes and sizes from a wide variety of materials. This is a process that creates powders or suspensions from droplets of a solution with a dissolved selected material ${ }^{1,2}$. There are variants of this process in terms of droplet generation, droplet-transportation orientation and final nanoparticle collection. However, the process is always the same and follows these steps: droplet generation, droplet transportation into the heating zone, particle formation from the droplet, particle collection.

Ultrasonic spray pyrolysis (USP) uses ultrasound to produce aerosol droplets from a precursor solution, a carrier gas for the transportation of the aerosol to the reactor furnace, a reaction gas for the formation of nanoparticles (if needed), a reactor furnace for the nanoparticle formation and a collection system for nanoparticles. The principle of nanoparticle production lies in the use of heavily diluted precursor solutions and the creation of small droplets. Ultrasound produces very small aerosol droplets in the range of a few micrometers in diameter (from $1 \mu \mathrm{m}$ to $10 \mu \mathrm{m}$ ), or more, depending on the ultrasound frequency and the parameters of the used solution $^{3}$. Using small solution concentrations the micronsized droplets are evaporated and the quantity of the dried solute particles left behind is in the nano-range. By

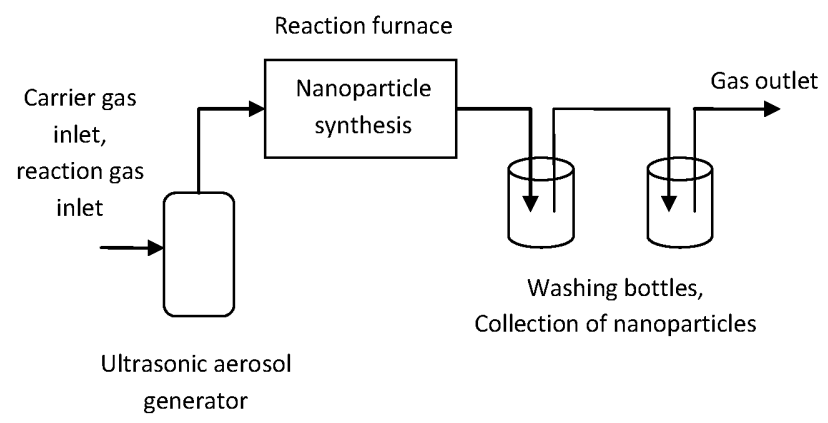

Figure 1: Schematic of the USP appliance previously used for the nanoparticle synthesis

Slika 1: Shema naprave USP, uporabljene za sintezo nanodelcev 
increasing or decreasing the solute concentration inside the droplet, greater or smaller nanoparticles can be acquired. In theory, every aerosol droplet produces one nanoparticle. This is known as the one-particle-per-droplet mechanism².

For the gold-nanoparticle production with USP we used a solution of hydrogen tetrachloroaurate $\left(\mathrm{HAuCl}_{4}\right)$ with nitrogen as the carrier gas for the aerosol droplets and hydrogen for the reduction of dried gold-chloride particles into gold nanoparticles. In the previous publications we reported synthesizing gold nanoparticles of different sizes and differing shapes such as irregular, spherical, triangular and cylindrical size ${ }^{4}$. We also noticed some unexpected processes, such as the formation of nanoparticles inside the ultrasonic aerosol generator. This caused a change in the color of the initial precursor solution from a clear yellow to a dark brown solution after the synthesis.

The formation of gold nanoparticles occurs at relatively low temperatures during spray pyrolysis (theoretically, a decomposition of $\mathrm{HAuCl}_{4}$ begins at $\left.258{ }^{\circ} \mathrm{C}\right)^{5}$. This means that the conditions of the aerosol formation via ultrasound and the presence of the reduction hydrogen gas inside the generator may cause the nanoparticles to start forming inside the generator (Figure 1). A solution was proposed for this problem, where the reduction gas would be introduced at a later stage when the aerosol is already formed. This also provides for an opportunity to connect a separate evaporation stage to the current synthesis set-up.

The separate evaporation stage would ensure the formation of dried spherical particles of gold chloride before the reaction stage involving hydrogen. The separate heating zone (the evaporation stage) could accomplish this using the low temperatures required for a slow evaporation of the solvent. Theoretically, when the solvent (water) evaporation is slow enough, the solute (gold chloride) will diffuse into the center of a droplet, forming a dried spherical particle (Figure 2) ${ }^{6}$ and, without the reaction gas present at this stage, the particles of gold chlorides cannot form on the surfaces of the droplets.

After the evaporation, hydrogen gas is introduced into the next heating zone (the reaction stage) and dried particles are reduced from gold chloride to gold. The particles are then collected for analysis. The dried-nano-

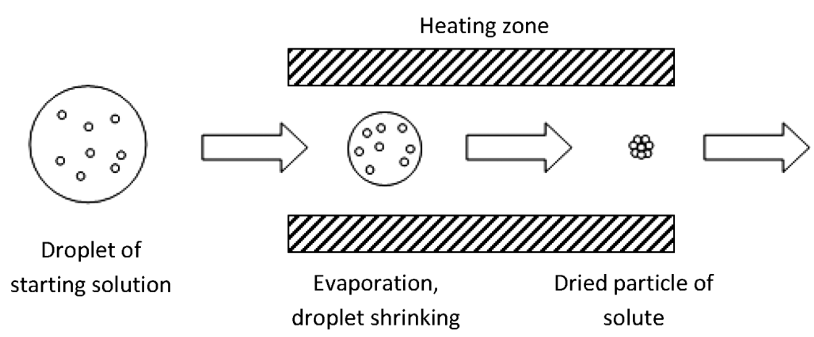

Figure 2: Simple presentation of the evaporation of an aerosol droplet with solute precipitation

Slika 2: Enostavna predstavitev izhlapevanja kapljice aerosola in izločanje topljenca particle form can also be an indicator of the final nanoparticle form (Figure 2). For this reason, spray drying was utilized, with which we acquired dried particles only from $\mathrm{HAuCl}_{4}$ solution droplets. These experiments are only discussed briefly in this article. There are descriptions of several models of the solute precipitation from a drying solution droplet ${ }^{6}$, where the predicted dried-particle form depends largely on the solution concentration, the droplet size, the evaporation rate and the solubility of the solute, while other parameters, such as the relative humidity and the aerosol-droplet quantity, do not affect the dried-particle formation so much.

In our research for the application of the produced gold nanoparticles in medicine it was shown that the sizes of around $50 \mathrm{~nm}$ nominally lead to the best results regarding cytotoxicity and biocompatibility ${ }^{7}$. From a theoretical standpoint this means that low concentrations of gold should be used in the precursor solution. Low concentrations of the material in the precursor solution for the nanoparticle production also provide better conditions for a solid, spherical nanoparticle formation ${ }^{8}$.

The separate evaporation zone with USP allows a better control of the particle formation during the first stages of the synthesis process. This, in turn, allows a production of more uniformly spherical nanoparticles, which are better suited for the applications in medicine compared to the mixture of nanoparticles of spherical, triangular and cylindrical shapes.

\section{MATERIALS AND METHODS}

For the aerosol-droplet generation we used an ultrasonic nebulizer Gapusol 9001 RBI (France), with an ultrasonic frequency of $2.5 \mathrm{MHz}$. The carrier gas, nitrogen, was passed through the nebulizer into the tubes leading towards the furnaces. Two tube furnaces were used; the first one was kept at the lower temperatures required for the evaporation, while the second one was kept at the higher temperatures, required for the nanoparticle-synthesis reactions. Hydrogen gas was released into the tubes between the furnaces to prevent a premature nanoparticle reduction before the droplets were completely evaporated (Figure 3). The washing bottles were filled with water for particle collection.

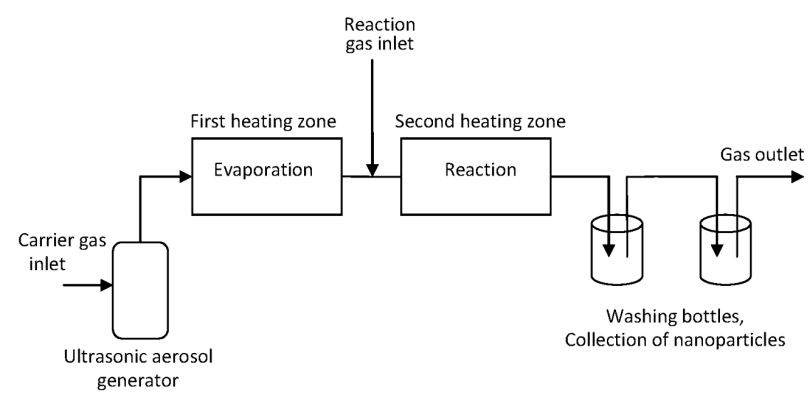

Figure 3: Schematic of the modified USP appliance used for experiments

Slika 3: Shema spremenjene naprave USP za izvedene eksperimente 


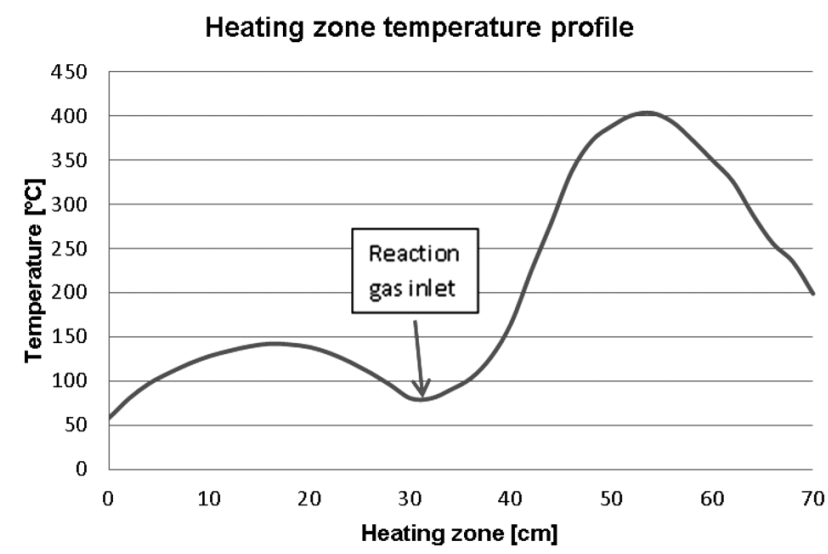

Figure 4: Temperature profile of the heating zone for aerosol-droplet evaporation (left side, before the gas inlet) and nanoparticle reactions (right side, after the gas inlet)

Slika 4: Temperaturni profil ogrevanega območja za izhlapevanje kapljic aerosola (leva stran grafa - pred vstopom plina) in reakcije nanodelcev (desna stran grafa - po vstopu plina)

The precursor solution in the aerosol generator was kept at $21{ }^{\circ} \mathrm{C}$ with a thermostat. The generated aerosol was carried into the evaporation heating zone via the quartz tubes with a diameter of $20 \mathrm{~mm}$ by nitrogen gas at a flow rate of $1.5 \mathrm{~L} / \mathrm{min}$. The residence time of the droplets/dried particles in the evaporation zone was $3.77 \mathrm{~s}$. Both heating zones were $30 \mathrm{~cm}$ long, with a $5 \mathrm{~cm}$ gap between them for the reduction-gas inlet. The reduction gas, hydrogen, was passed into the tubes between the heating zones at a flow rate of $1 \mathrm{~L} / \mathrm{min}$. The residence time of the particles inside the second heating zone was $2.26 \mathrm{~s}$.

The temperature profile of the two furnaces was measured prior to the nanoparticle synthesis using only water for the aerosol generation and nitrogen gas at both gas inlets (Figure 4).

In order to determine the feasibility of dried-nanoparticle collection a few experiments were performed with only the first furnace and without hydrogen gas (Figure 5). The aim of these experiments was to determine the morphology of dried particles from aerosol droplets before the final nanoparticle reactions. The particles were collected on a filter paper as they were assumed to be the particles of gold chloride. As gold

Table 1: Experiments performed with the USP device Tabela 1: Eksperimenti, izvedeni z USP-napravo

\begin{tabular}{|c|l|c|c|}
\hline $\begin{array}{c}\text { Experi- } \\
\text { ment }\end{array}$ & \multicolumn{1}{|c|}{ Type } & $\begin{array}{c}\text { Au solution } \\
\text { concentration } \\
(\mathrm{g} / \mathrm{L})\end{array}$ & $\begin{array}{c}\text { Collection } \\
\text { medium }\end{array}$ \\
\hline 1 & Droplet evaporation & 0.5 & Filter paper \\
\hline 2 & Droplet evaporation & 1.25 & Filter paper \\
\hline 3 & Droplet evaporation & 2.5 & Filter paper \\
\hline 4 & Nanoparticle synthesis & 0.5 & Water \\
\hline 5 & Nanoparticle synthesis & 1.25 & Water \\
\hline 6 & Nanoparticle synthesis & 2.5 & Water \\
\hline 7 & Nanoparticle synthesis & 5 & Water \\
\hline
\end{tabular}

chloride is highly soluble it would not be possible to collect it in wash bottles containing water, alcohol, or similar.

The experiments performed are presented in Table 1.

TEM images with an EDS analysis were used for the nanoparticle characterization.

\section{RESULTS AND DISCUSSION}

A number of thermal measurements were performed to ensure the best possible conditions for the particle formation. The temperatures measured were from $60{ }^{\circ} \mathrm{C}$ to $140{ }^{\circ} \mathrm{C}$ for the first furnace and from $250{ }^{\circ} \mathrm{C}$ to $400{ }^{\circ} \mathrm{C}$ for the second furnace. At the very low temperature settings $\left(60-80{ }^{\circ} \mathrm{C}\right)$ for the first furnace, more condensation was observed in the tubes, resulting in an aerosol droplet loss with the synthesis. To avoid the needless condensation, the temperature at which no condensation was observed in the first furnace was selected. Condensation of aerosol droplets reduces the nanoparticle output.

A reasonable temperature was selected for the second furnace, where the temperature has to be high enough to allow for the gold-nanoparticle formation while ensuring a complete reaction so that no unreacted particles exit in the second furnace. The temperature profile of the heating zones is shown in Figure 5.

In the previous experiments of the nanoparticle synthesis with USP gold nanoparticles of different shapes were obtained without a separate evaporation stage. The collected nanoparticles were of spherical, irregular, triangular and cylindrical shapes ${ }^{4}$. In comparison, separating the evaporation stage from the reaction and densification stages yielded mostly non-ideally spherical nanoparticles and some irregularly shaped nanoparticles. Lower concentrations of gold in the precursor yielded less irregular shapes of the nanoparticles.

The average nanoparticle sizes were also reduced by separating the droplet evaporation from the rest of the process. Using a precursor solution with $2.5 \mathrm{~g} / \mathrm{L} \mathrm{Au}$ and an ultrasound frequency of $2.5 \mathrm{MHz}$, sizes ranging from 10-250 nm were obtained without a separate evaporation zone $^{4}$ (Table 2). With a separate evaporation zone, sizes ranging from 10-80 $\mathrm{nm}$ were obtained (Figure 6 and Table 2). It seems there are less agglomeration and par-

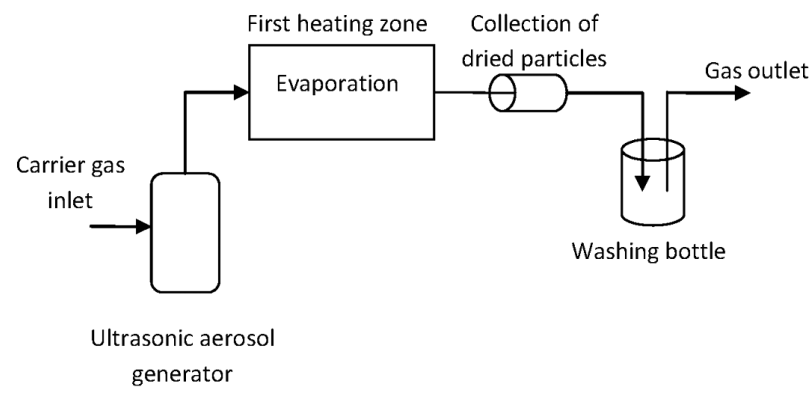

Figure 5: Schematic of the device for dried-nanoparticle-collection experiments

Slika 5: Shema naprave za preizkus zbiranja posušenih nanodelcev 
ticle growth present when the nanoparticles are synthesized with a separate evaporation zone.

Table 2: Comparison of nanoparticle sizes after USP synthesis with and without a separate evaporation zone

Tabela 2: Primerjava velikosti nanodelcev pri sintezi z USP brez ločenega območja za izhlapevanje in z njim

\begin{tabular}{|c|c|c|}
\hline USP & $\begin{array}{c}\text { Gold concentration } \\
\text { in precursor } \\
\text { solution }\end{array}$ & $\begin{array}{c}\text { Synthesized } \\
\text { gold-nanoparticle } \\
\text { size distribution }\end{array}$ \\
\hline $\begin{array}{c}\text { Without a separate } \\
\text { evaporation zone }\end{array}$ & $2.5 \mathrm{~g} / \mathrm{L}$ & $10-250 \mathrm{~nm}$ \\
\hline $\begin{array}{c}\text { With a separate } \\
\text { evaporation zone }\end{array}$ & $2.5 \mathrm{~g} / \mathrm{L}$ & $10-80 \mathrm{~nm}$ \\
\hline
\end{tabular}

The sizes of the nanoparticles are generally accepted to be mainly dependent upon the precursor concentration and droplet size. In our experiments, the droplet sizes are considered to be the same in each experiment, while the precursor concentration was changed for each experiment. With a gold concentration of $5 \mathrm{~g} / \mathrm{L}$ in the precursor solution we obtained nanoparticles in the size range from around $50 \mathrm{~nm}$ up to $300 \mathrm{~nm}$. While there are small nanoparticles present, the bulk of the nanoparticles have a diameter of about $200 \mathrm{~nm}$. There are also a bigger number of irregularly shaped nanoparticles, with less spherical nanoparticles present. More agglomeration is also observed when using such a precursor solution concentration. The separate evaporation zone seems to be beneficial for the production of more uniformly shaped nanoparticles as the irregularly shaped nanoparticles have round edges even though they are not spherical. When not using the separate evaporation zone, nanoparticles have sharper edges in the form of triangles and discs and irregular shapes with sharp edges ${ }^{4}$. Such shapes did not appear in the case of the separate evaporation zone. The separate evaporation zone is, therefore, favorable in order to obtain only spherical shapes of the nanoparticles produced with USP.

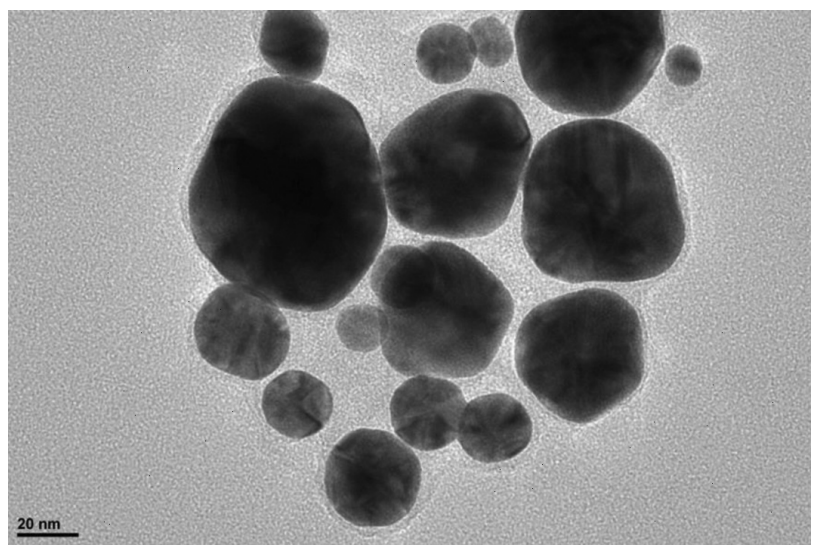

Figure 6: TEM image of gold nanoparticles obtained with USP with a separate evaporation zone; gold concentration in precursor solution: $2.5 \mathrm{~g} / \mathrm{L}$

Slika 6: TEM-posnetek nanodelcev zlata, pridobljenih z USP z ločenim območjem za izhlapevanje; koncentracija zlata v začetni raztopini: $2,5 \mathrm{~g} / \mathrm{L}$
With a gold concentration of $2.5 \mathrm{~g} / \mathrm{L}$ in the precursor solution, we obtained sizes ranging from $10 \mathrm{~nm}$ to $80 \mathrm{~nm}$. The average size of the nanoparticles with such a concentration is $55 \mathrm{~nm}$. The shapes of the nanoparticles are still not ideally spherical as there are still particles with irregular shapes present. However, even though they are not ideally spherical, their shapes appear to have a high order of sphericity, with the smaller nanoparticles being more spherical than the bigger ones.

A gold concentration of $1.25 \mathrm{~g} / \mathrm{L}$ in the precursor solution yielded nanoparticles in the range from $10 \mathrm{~nm}$ to $40 \mathrm{~nm}$. The bulk of the nanoparticle sizes are about $20 \mathrm{~nm}$. With a precursor concentration of $0.5 \mathrm{~g} / \mathrm{L}$ of gold in the solution the nanoparticle sizes obtained were from $10 \mathrm{~nm}$ to $40 \mathrm{~nm}$, with the average nanoparticle size being somewhat smaller, around $15 \mathrm{~nm}$.

The shapes of the nanoparticles with gold concentrations of $(2.5,1.25$ and 0.5$) \mathrm{g} / \mathrm{L}$ in the precursor solution are very similar. With all three concentrations we obtained a mixture of spherical and irregularly shaped nanoparticles (Figures 6 and 7).

The separate evaporation zone yielded better results regarding the uniformity of the shapes and sizes with higher gold concentrations $(2.5 \mathrm{~g} / \mathrm{L}$ and $5 \mathrm{~g} / \mathrm{L})$ in the precursor. Even though the shapes are still not ideally uniform, less diverse shapes are produced while using the separate evaporation zone in the USP process. The sizes of the obtained nanoparticles are also less dispersed. In this regard, the separated evaporation zone is useful for producing gold nanoparticles of more similar shapes and sizes with USP. This is not apparent when using lower gold concentrations $(0.5 \mathrm{~g} / \mathrm{L}$ and $1.25 \mathrm{~g} / \mathrm{L})$. With lower concentrations, solid spherical shapes are formed more readily with USP, and the benefits of the separate evaporation zone are not seen so easily (Figure 7). From a theoretical standpoint, using a low concentration in the precursor solution is effective for producing solid and more uniform nanoparticles with the standard USP

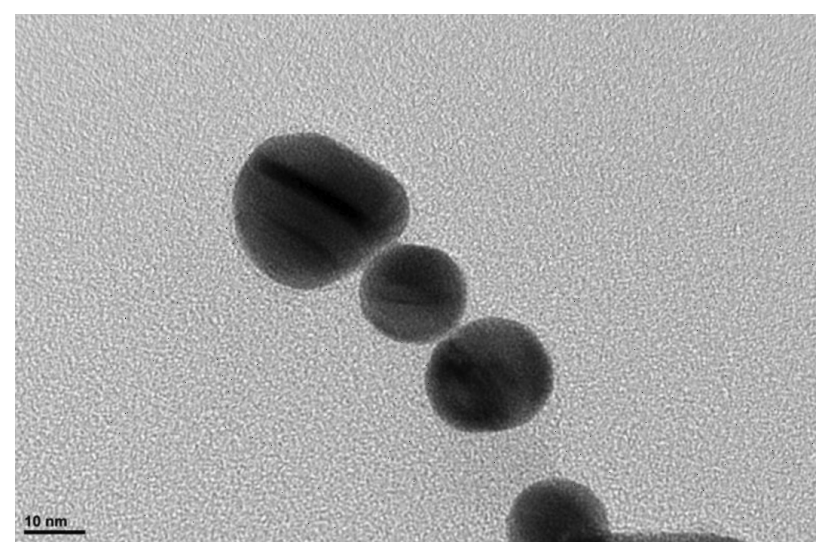

Figure 7: TEM image of gold nanoparticles obtained with USP with a separate evaporation zone, gold concentration in precursor solution: $0.5 \mathrm{~g} / \mathrm{L}$

Slika 7: TEM-posnetek nanodelcev zlata, pridobljenih z USP z ločenim območjem za izhlapevanje; koncentracija zlata $\mathrm{v}$ začetni raztopini: $0,5 \mathrm{~g} / \mathrm{L}$ 
process. Even though spherical shapes of the nanoparticles were formed in our experiments with the modified USP process, irregular shapes were also present.

As a result, it is difficult to determine the effectiveness of the separate evaporation zone when using lower concentrations of gold in the precursor solution. More work is needed with regard to the other synthesis parameters in order to determine the feasibility of using the separate evaporation zone when using lower gold concentrations in the precursor solution. However, from a technological point of view, the separate evaporation zone eliminates the reactions with hydrogen and the particle formation inside the ultrasound generator. The precursor solution remained the same before and after the nanoparticle synthesis, which is a good indicator of this technical issue being resolved, compared to the standard USP set-up where the precursor solution changes after the experiment.

The separate evaporation zone used in our experiments gave some favorable results with respect to reducing the nanoparticle-size distribution and producing more uniformly shaped nanoparticles. In order to advance the research in the direction of producing uniform shapes, other parameters, such as the gas flow, should be studied experimentally, or further modifications should be made to the USP process.

In the experiments with the droplet evaporation the produced particles were collected on a filter paper made from cellulose in order to prevent a re-dissolving of the gold chloride particles. This collection yielded two substances, or types of particles, visible on the filter paper after the collection. On the edges of the used filter paper a purple substance was collected, while at the center of the filter paper we collected a yellowish substance. This suggests that two chlorides of gold were collected: $\mathrm{AuCl}$ appeared in the form of yellow crystals, while $\mathrm{AuCl}_{3}$ appeared in the form of red crystals ${ }^{9}$.

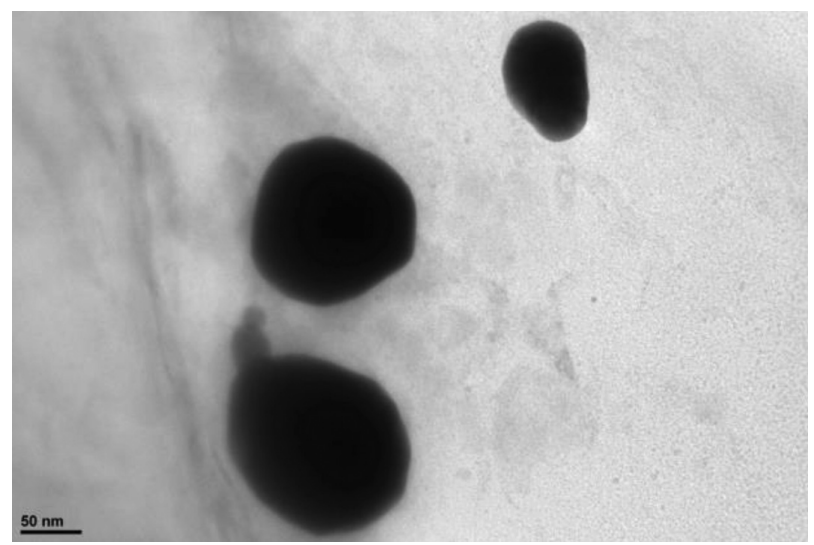

Figure 8: Nanoparticles collected on filter paper after evaporation, created with a gold concentration of $1.25 \mathrm{~g} / \mathrm{L}$ in the precursor solution Slika 8: Nanodelci, zbrani na filter papirju po izhlapevanju, narejeni s koncentracijo zlata $1,25 \mathrm{~g} / \mathrm{L}$ v začetni raztopini
It is assumed that the nanoparticle morphology is dependent mainly upon the evaporation stage. The optimum drying of the aerosol droplets theoretically produces solid, spherical particles of the dried solute. In order to check the feasibility of dried-nanoparticle collection after the evaporation, the particles were first collected on filter paper (Figure 8). The particles collected in this way are difficult to characterize and an improved method for collecting dried nanoparticles will be utilized in future research for an easier particle characterization after the collection.

After the collection of dried particles, the correlation of dried particles with the final nanoparticles is examined. This insight into the separate synthesis stages provides a better understanding of the process and allows us to produce a more accurate model for determining the gold-nanoparticle synthesis with a separate evaporation zone.

\section{CONCLUSION}

Gold nanoparticles were synthesized using USP with a separate evaporation zone. The gold concentration in the precursor solution used for the aerosol generation was the primary variable parameter in order to determine the effects of the separate evaporation zone on the final nanoparticle sizes and shapes. When using higher concentrations of gold in the precursor solution, the experiments showed more uniformly shaped nanoparticles in the case of the separate evaporation zone compared to the standard USP set-up. A narrower size distribution of the gold nanoparticles was also obtained in comparison to the standard USP set-up. When using lower gold concentrations in the precursor solution, these advantages are not so obvious. As the separate evaporation zone does not entirely prevent the presence of irregularly shaped nanoparticles, similar nanoparticles can be obtained without a separate evaporation zone at low precursor-solution concentrations. However, it is apparent that separating the evaporation stage from the reaction and densification stages improved the process to some extent so that more nanoparticles of spherical shapes and more uniform sizes are produced. The produced nanoparticles are smaller in size $(10-80 \mathrm{~nm}$ for $2.5 \mathrm{~g} / \mathrm{L} \mathrm{Au}$ in the precursor solution) compared to the nanoparticles produced without a separate evaporation zone (10-250 nm for 2.5 $\mathrm{g} / \mathrm{L} \mathrm{Au}$ in the precursor solution). Further work on the modifications and parameter optimization is now needed to improve the process in pursuit of gold nanoparticles with uniform shapes and as narrow a nanoparticle-size distribution as possible.

\section{Acknowledgment}

We would like to thank Dr. Darja Jenko for performing the TEM analysis on the Au nanoparticles. This research was made possible by the Slovenian Research Agency (ARRS), the Young Researcher Program and the 
Slovenian Public Fund for the Development of Human Resources.

\section{REFERENCES}

${ }^{1}$ G. L. Messing, S. C. Zhang, G. V. Jayanthi, Ceramic Powder Synthesis by Spray Pyrolysis, J. Am. Ceram. Soc., 76 (1993) 11, 2707-2726, doi:10.1111/j.1151-2916.1993.tb04007.x

${ }^{2}$ S. C. Tsai, Y. L. Song, C. S. Tsai, C. C. Yang, W. Y. Chiu, H. M. Lin, Ultrasonic spray pyrolysis for nanoparticles synthesis, J. Mater. Sci. 39 (2004) 11, 3647-3657, doi:10.1023/B:JMSC.0000030718.76690.

11

${ }^{3}$ J. Bogović, A. Schwinger, S. Stopic, J. Schröder, V. Gaukel, H. P. Schuchmann, B. Friedrich, Controlled droplet size distribution in ultrasonic spray pyrolysis, Metall, 65 (2011) 10, 455-459

${ }^{4}$ S. Stopic, R. Rudolf, J. Bogovic, P. Majeric, M. Colic, S. Tomic, M. Jenko, B. Friedrich, Synthesis of Au nanoparticles prepared by ultrasonic spray pyrolysis and hydrogen reduction, Mater. Tehnol., 47 (2013) 5, 577-583
${ }^{5}$ R. Dittrich, S. Stopic, B. Friedrich, Mechanism of nanogold formation by ultrasonic spray pyrolysis, Proceeding of the EMC Conference, Düsseldorf, Germany, 2011, 385

${ }^{6}$ G. V. Jayanthi, S. C. Zhang, G. L. Messing, Modeling of Solid Particle Formation During Solution Aerosol Thermolysis: The Evaporation Stage, Aerosol Sci. Technol., 19 (1993) 4, 478-490, doi:10.1080/02786829308959653

${ }^{7}$ S. Tomić, J. Đokić, S. Vasilijić, N. Ogrinc, R. Rudolf, P. Pelicon, D. Vučević, P. Milosavljević, S. Janković, I. Anžel, J. Rajković, M. S. Rupnik, B. Friedrich, M. Čolić, Size-Dependent Effects of Gold Nanoparticles Uptake on Maturation and Antitumor Functions of Human Dendritic Cells In Vitro, PLoS ONE, 9 (2014) 5, e96584, doi:10.1371/journal.pone.0096584

${ }^{8}$ T. T. Kodas, M. J. Hampden-Smith, Aerosol Processing of Materials, 1st edition, Wiley-VCH, New York 1998

${ }^{9}$ D. R. Lide (Ed.), CRC Handbook of Chemistry and Physics, 80th Edition, CRC Press, Boca Raton 1999 